\title{
Trends and Innovations in Value Chain Management of Tropical Fruits
}

\author{
Harinder Singh Oberoi* and Dinesh M.R. \\ ICAR-Indian Institute of Horticultural Research, Hessaraghatta, Bengaluru, India \\ *Corresponding author, email: harinder.oberoi@icar.gov.in
}

\begin{abstract}
India produced about 97.35 million tons of fruits during 2017-18, of which less than $1 \%$ fruits were exported. In India, less than $5 \%$ of the total fruits produced are sold by the organized supply chain management and E-commerce companies and $3 \%$ of the total produce gets processed, indicating that more than $90 \%$ of fruits follow the traditional route of supply chain involving farmers, auctioneers, agents/intermediaries, wholesalers, sub-wholesalers, retailers, cart vendors before they reach the consumers. Post-Harvest (PH) losses occur at each stage of the supply chain and are compounded with each operation. A study on PH loss estimation has shown maximum loss of $15.88 \%$ in guava among fruits while other studies have reported much higher PH lossesin fruits. Value of tropical fruits, both in monetary terms and quality reduces during harvesting, handling, transportation from the farmer's field, packaging, storage, retail and even at the consumer's level. Important interventions that reduce the $\mathrm{PH}$ losses and improve the supply chain management are establishment of pre-cooling facilities and short term storage facilities through evaporative cooling/refrigeration mechanisms at the farm gate, primary processing and packaging provision at the farm gate or nearby collection centres, transportation of fruits in refrigerated/evaporative cooled vans with the use of alternate energy sources and provision for low temperature and high humidity storage at the retail centres. Establishment of a Postharvest management system for sorting, washing, partial drying, edible coating, if required and grading at the collection centres will help in reducing the PH losses in the supply chain and help farmers get a better value for their produce. Formation of farmer clusters or Farmers Producer Organizations (FPOs) provides farmers a better bargaining power because of higher volumes. Educating and bringing awareness among the farmers about the good agricultural practices (GAP), mechanization in field operations, availability of seeds for different seasons, eliminating the problem of seasonality are also important in production of quality output. Transportation of fruits, such as mango, banana and guava in vans/wagons operating through evaporative cooling/ cooling mechanism using phase change material will help in improving the shelf life of such fruits. An integrated radio frequency identification (RFID) system along with the sensors for ethylene, temperature and RH monitoring is likely to help in easy tracking and traceability of the fresh produce. Establishment of primary and secondary processing facility at the farmer cluster/ FPO levels will help in transforming the farmers to primary processors.
\end{abstract}

Keywords: Collection centres, Packaging, Post-Harvest management, Supply chain, Transportation and Value chain

\section{INTRODUCTION}

India is the second largest producer of fruits and vegetables in the world and even the largest producer for some of the tropical fruits, such as papaya, mango and banana. As per the report of National Horticulture Board (NHB), fruit and vegetable production during
2017-18 in India was 97.35 and 187 million tonnes, respectively. India exported about 0.69 million tons of processed fruits and vegetable products, earning a revenue of about Rs 5279 crores in 2018-19, while the export of about 3.80million tons of fresh fruits and vegetables during 2018-19 fetched a revenue of about 
Rs 10,338 crores according to Agricultural and Processed Food Export Development Authority (APEDA). Export of fresh fruits from India during 2018-19 was less than $1 \%$ of the total quantityof the fruits produced in the country. As per Ministry of Food Processing Industries (MOFPI) data, only $2-2.2 \%$ fruits are processed in India. Organized supply chain management companiesin India like Reliance Fresh, Big Bazaar, Aditya Birla Retail Ltd or E-commerce companies like Big Basket or Grofers etc. account for procurement of less than $5 \%$ of the total fruits produced in the country. This data indicates that more than $90 \%$ of fresh fruits pass through the traditional supply chain involving farmers, auctioneers, agents/ intermediaries, wholesalers, sub-wholesalers, retailers, cart vendors and consumers as mentioned elsewhere in this paper. As the fresh perishable produce has to pass through several hands/ steps, Post-Harvest (PH) losses occur at each stage before the fruits actually reach the consumers. In addition to the measurable losses, a deterioration in quality (intangible loss) of the fruits takes place at each step, indicating that there are both quality and quantity losses in such a long supply chain having a direct impact on the value of the fresh produce. Losses even occur at the level of the consumers that cannot even be estimated.

Studies on PH losses in fruits and vegetables have reported maximum losses in guava at $15.88 \%$ among all the fruits (Jha et al., 2015). However, authors considered only eight fruits for $\mathrm{PH}$ loss estimation study viz., apple, banana, citrus, grapes, guava, mango, papaya andsapota. Salami et al. (2010) have reported losses in fruits and vegetables between harvest and final consumption at about $30-40 \%$. Therefore, it becomes imperative to reduce the number of operations from farm-to-fork in order to retain the value of the fruits both from the quality and nutrition perspectives and minimize the $\mathrm{PH}$ losses.

\section{Value chain model for horticultural crops}

Value chains describe the full range of activities which are required to bring a product or service from conception, through the different phases of production (involving a combination of physical transformation and the input of various producer services) delivery to final disposal after use (Kaplinsky and Morris, 2000). Value chain integrates various factors together and provides communication of market information to all the players involved in the chain.
Supply chain activities consist of buying produce (purchasing), changing something about the produce to increase its value (processing e.g. packaging and/ or sorting) and transporting it to the location of demand (distribution). The demand chain consists of activities to stimulate demand for produce (marketing), facilitating transactions to enable people to buy the produce (sales) and providing any 'after-sales' service such as dealing with returns or unsold perishable goods (service).

Value chain encompasses different facets of supply and demand chain, starting from the land use planning, adoption of good agricultural practices (GAP), nutrient and agro-chemicals use management, precision farming for production of a good quality and uniform produce; supply chain management, discussed in detail elsewhere in this paper; market intelligence and demand forecasting/crop planning for fruits and vegetables and marketing of the fresh as well as processed fruits. Therefore, value chain for fruits is extremely important as it integrates different links together, starting from farmer/ FPO to consumer through different approaches. Value chain analysis of mango cultivation in one acre of land in Dharwad, Karnataka is presented in Fig.1. The input details and the price that the farmer gets in the market are obtained from the farmer who has mango plantations spread over 9 acres. Though the farmer is the primary producer of the crop, he gets least value for his produce, whereas the major share of value addition is distributed among the traders (intermediaries) and retailers. Despite the fact that the major stakeholder in this value chain is a farmer, he accounts for about $12 \%$, whereas the retailers account for about $60 \%$ and the traders for about $30 \%$ in the value chain.

Smallholder (farmer's) participation in the tropical fruits value chain is constrained by inadequate farmlevel resources, farm-to-market logistical bottlenecks and transaction costs in matching and aggregating dispersed supplies to meet buyer and consumer demands (Chang et al., 2014). These constraints are compounded by a new set of challenges associated with compliance with product and process standards enforced by the government agencies or supply chain management companies. Some of the major reasons for low-level participation of the smallholders/ farmersin the tropical fruit value chain in countries like Indiaare: 
- Fragmented land holdings and low farm outputs which reduce the bargaining power of the individual farmers. It is therefore important to have the farmer co-operatives or FPOs who can have a better bargaining power vis-à-vis wholesalers or intermediaries.

- Lack of market intelligence, poor linkages to market and inadequate market information, distance from the farmer's fields to the retail markets and poor roads and transportation systems compound the problems for farmers.

- Lack of effective policies, including access to credit, on-farm infrastructure for storage, handling or primary processing of fruits, appropriate quality standards and compliance mechanism and lack of proper pre. and post. harvest technologies limit the involvement of the individual farmers in the value chain.
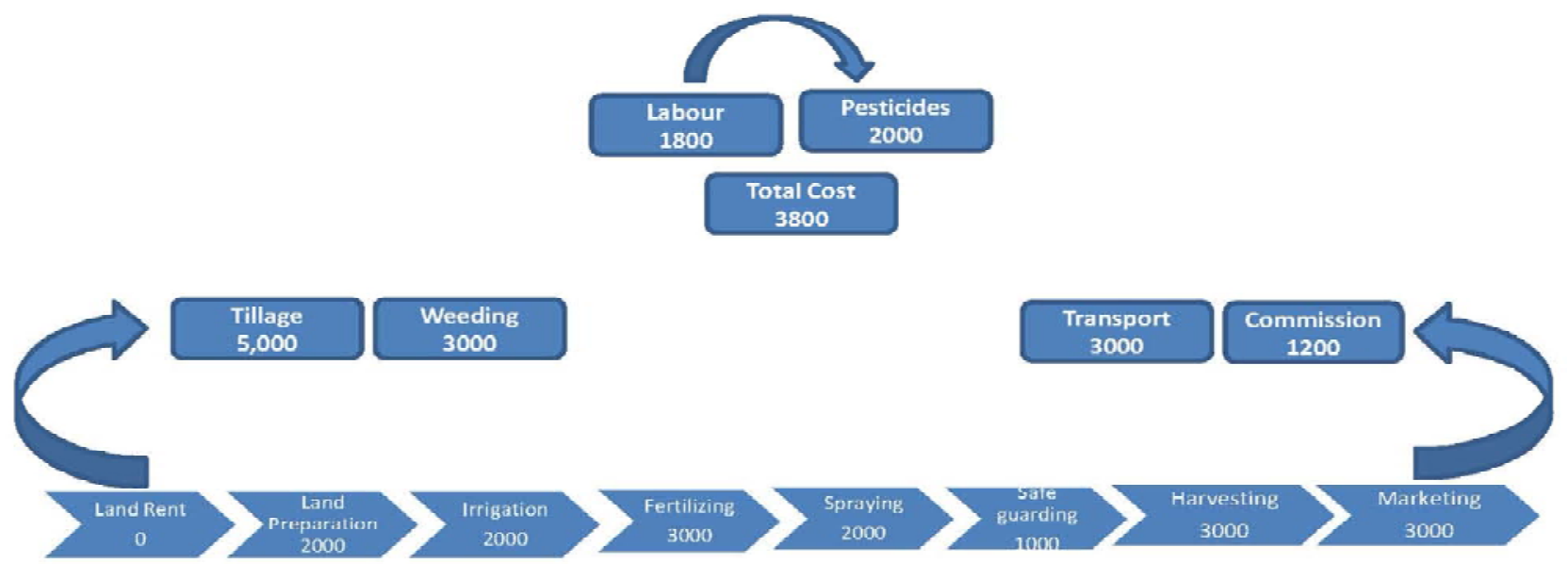

\begin{tabular}{|l|l|}
\hline \multicolumn{2}{|c|}{ Benefit Cost Analysis /Acre } \\
\hline Production Cost & $: 32000$ \\
\hline Total Yield & $: 2000 \mathrm{~kg}$ \\
\hline Selling price/kg & $: 20.0$ \\
\hline Total Revenue & $: 40000$ \\
\hline Profit/Acre & $: 8000$ \\
\hline Benefit Cost Ratio & $: 1.25: 1$ \\
\hline
\end{tabular}

\begin{tabular}{|l|r|r|r|}
\hline \multicolumn{5}{|c|}{ Value addition of the Value Chain Actors } \\
\hline Value Chain Actors & \multicolumn{1}{|c|}{ Average Price } & \multicolumn{1}{|c|}{ Value Addition } & Value Addition (\%) \\
\hline Inputs & 16.0 & - & - \\
\hline Farmers & 20.0 & 4.00 & 11.76 \\
\hline Traders & 30.00 & 10.00 & 29.41 \\
\hline Retailers & 50.00 & 20.00 & 58.81 \\
\hline Total & - & 34.00 & 100 \\
\hline
\end{tabular}

Fig. 1: Value chain analysis of Mango cv. Alphonso (1 acre) in Dharwad, Karnataka (Input details for production of fruits and market price of the fruit are presented for illustration purpose and may vary from farm to farm, place to place and the method of cultivation)

\section{Production and crop planning}

Value chain begins with the farmer and the agricultural practices followed by the farmers in production of uniform and quality produce. Highest amount of waste in fruits and vegetables supply chain occurs at the farm gateitself. Even today, traditional cropping patterns are prevalent in most parts of India. For example, high density and ultra-high density plantations of tropical fruits, such as mango and guava increase the productivity as well as quality of the product, therebyhelping farmers to get better price for their produce. Problem of seasonality in fruits and vegetables could be handled largely using seeds available for different seasons.Application of GAP is widely recognized as the most important measure in assuring the safety of fresh produce, followed by the application of good hygienic practices (GHP) and the certification of food safety management systems (FSMS). Pre-harvest factors which have a profound influence on the $\mathrm{pH}$ quality attributes are the use of quality irrigation water (main source of contamination); maintenance or restoration of soil organic carbon, crop rotation, avoiding water and fertilizer run-off, water recycling, etc., help in better quality output and minimizing the incidence of pathogen infestation, such as that of Aspergillus spp, largely responsible for production of aflatoxins. Mechanization 
in land preparation, planting, irrigation and pest and disease management are important components of GAP, which help in production of a good quality output.

In order to tackle the issues of perishability and seasonality of fruits and vegetables, it is important for the procurement agencies (both government agencies and supply chain management companies) to work closely with the farmers and help them in crop planning. Farmers should also be informed about the nutrient use management, use of biopesticides, micronutrient formulation, high density planting and irrigation techniques. Such crop planning and market intelligence techniques will help in adding value to the produce and getting a good remuneration for farmers for their produce.

\section{Supply chain management of fruits in India}

Recent advances in food markets around the world are driven by consumer demand and preferences, food safety concerns and the increased bargaining power of modern retail systems. Higher income and changing lifestyles have led to demand for more variety, better quality, year-round supply of fresh produce, "healthy" food and convenience. In addition, consumer's concerns for safe foodand also about the social and environmental conditions under which food is produced has led us to believe that technological interventions are needed to strengthen the supply chain as well as product development. It therefore becomes important to preserve the value of important perishable commodities at each stage in the supply chain as well as during processing.

Traditional model of supply of fruits and vegetables in India (Fig.2) from farmer to consumer involves a series of intermediaries. Loss in quantity because of physiological lossesand quality loss due to poor handling occurs at each stage. In certain parts of the country, banana combs are stacked over one another and transported in open trolleys and mini trucks to the auction sites/ wholesale markets. As the village roads and the approach roads to auction sites/ wholesale markets are undulating, broken and have many potholes, spoilage in fruits is intensified. Losses are accumulated at each stage of the supply chain (Fig.2) and a long supply chain like the one being used in the conventional system leads to significant PH as well as quality loss in fruits.

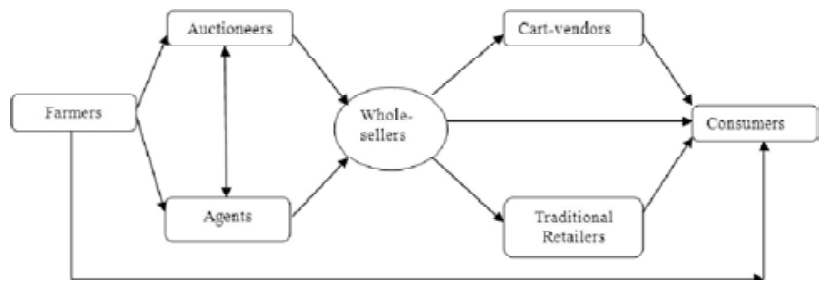

Fig. 2: Traditional supply chain system followed in India

Baskets made from bamboo with paddy straw as cushioning materials used as packaging for fruits like papaya and mangoes in various parts of the country (Fig. 3) result in very high spoilages during storage and transportation. All these losses reduce the value of the fruit in monetary terms for farmers, leading to distress sale. Traditional supply chain for fresh fruits in most cases does not fetch a good remuneration for the farmers.

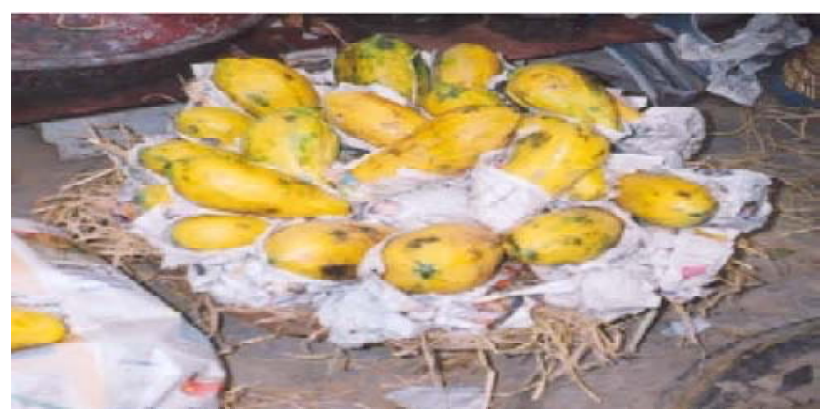

Fig. 3: Packaging of mangoes in bamboo baskets with paddy straw as cushioning material

Supply chain being followed by the organized companies like Reliance Fresh and Aditya Birla Retail Ltd (More) in India isrelatively shorter than the traditional supply chain. Both these companies directly procure the produce from the farmers/ farmer producer organizations (FPOs)/ farmer co-operatives/ clusters. On most occasions, sorting of the fruits is done at the farm gate and the desired fruits are only procured by such companies for supply to their retail stores. Supply chain model involves transportation of fresh fruits and vegetables to their collection centres (CC)/buying centres, where the fruits and vegetables are weighed, sorted, if necessary and shifted to the distribution centres (DC), where primary processing operations, such as grading, packaging into small retail packs is done and subsequently, the material is shifted to the retail stores of the respective companies or consumers directly by the E-commerce companies (Fig.4). Facilities like graders, conveyors, washers and cold stores are available at DCs of these companies. 
Reliance Fresh also deploys a fleet of refrigerated vehicles for transportation of the fruits to their retail stores. This kind of supply chain has helped in reducing the $\mathrm{PH}$ losses drastically. As per Sihariya et al. (2013) Reliance Fresh has successfully reduced the PH losses from the farmer's field to their retail stores from $25-30 \%$ to about $7-8 \%$ through precooling of harvest, better post-harvest handling (less number of human touches/contacts), and special type of packages for highly perishable products. Reliance also uses coldchain for inter-state movement of fruits and vegetables and regularly conducts trainings for the staff in the supply chain, which contribute significantly to alleviation in the PH losses. Waycool Foods and Products Pvt Ltd, Chennai, India procures most fruits and vegetable directly from the farmers and FPOs located in and around Chennai and nearby districts of Tamil Nadu and transport the fresh horticultural produce to their collection centre which has facilities for sorting, grading, weighing, washing and temperature controlled compartments for storage of highly perishable materials. The company repacks the produce in bulk packages for supply to wholesalers and retails packages for supply to their franchisee retail outlets. The company also has developed transport vehicle based on phase change material (PCM) for transport of highly perishable produce from their collection centre to retail outlets or wholesale markets. Waycool has placed the ICAR-IIHR developed Arka High Humidity storage boxes in their franchisee retail outlets for storage of green leafy and other vegetables, thereby significantly reducing the $\mathrm{PH}$ losses at the retail level.

Big Basket, a large E-commerce company that supplies about 100,000 tons of fresh fruits and vegetables annually procures a substantial quantity of and vegetables (about $80 \%$ ) directly from the farmers and FPOs and the remaining produce from other companies like Grofers, Waycool, etc. The company has its own CCs located near the production hubs, which have the basic facilities for weighing, sorting and grading. Fresh produce is directly transported from the CCs to DCs, where the fresh produce is graded, if required, repackaged in small packs, such as punnets for pomegranate, corrugated fibreboard (CFB) boxes for mangoes and papaya and transported directly to the consumer's doorstep. Some of the DCs of the company also have facilities for treatment and packaging of the selected fresh-cut fruits and vegetables. Highly perishable produce is transported either in refrigerated vans or in the containers with gel packs for small retail packs by the company.

Though the supply of fresh fruits and vegetables in an organized way by the above mentioned companies has brought down the $\mathrm{PH}$ losses significantly and have successfully added value to the fresh horticultural produce, these companies put together procure less than $5 \%$ of the total fruits produced in the country.

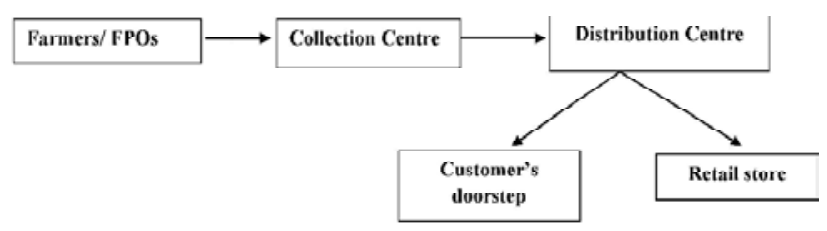

Fig. 4: Supply chain followed by the organized farm-to-fork companies for supply of fruits in India

\section{Supply chain management practices followed in other countries}

Supply of fruits and vegetables in most of the developed countries involves primary processing of fresh produce at the farm gate and supply of such produce to wholesalers/ agents, retailers and consumers directly (Fig.5). As per Jassi (2011), most of the produce after harvest is subjected to processing to increase the shelf life of the products and is then transported to wholesalers/ agents who deliver the product to the Hospitality industry and retail stores from where it reaches the consumer, which is considered as another good approach of saving the precious fruits and vegetables. In most developed countries, farmers supply fresh produce directly to the retail stores and at times to the consumer and the processing levels in such countries are substantially higher than that in India.

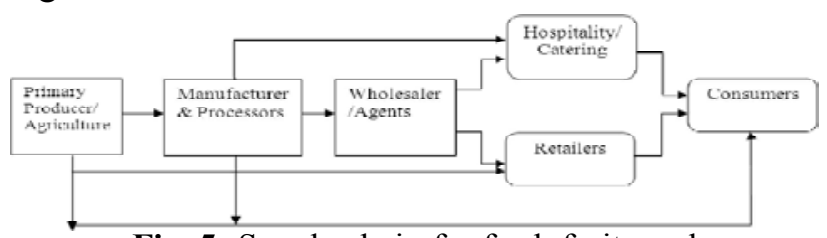

Fig. 5: Supply chain for fresh fruits and vegetables followed in developed countries

Thailand has similar climatic condition as India and so is the food consumption pattern. The supply chain in fruits and vegetables however is much better developed in Thailand as compared to India (Srimanee and Routray, 2012). Supermarkets in Thailand account for $40 \%$ of fruit and $30 \%$ of vegetables in urban 
areas, but a lower percentage in the context of the entire country (Fig. 6). Fresh fruits and vegetables have not only increased in percentage share of sales but also are very profitable relative to other products in the stores in Thailand. A consequence of the increasing importance of supermarkets for fruits and vegetables is that the procurement system has had an impact on small farmers, who are the major fruit producers in Thailand. The major channel from farmers to co-operative groups to supermarkets accounts for about $20 \%$ of supply of farmer's produce. There is no intermediaries between supermarkets and farmers' co-operative groups. This has reduced the incidence of multiple parties in the channel, thereby improving efficiency of the chain. Cooperatives and specialist assemblers are more beneficial to farmers, compared to other channels because of their openness and flexibility. Intermediaries of these channels are responsible for all the steps involved in grading, packaging and delivery, which are more efficient when carried out on a large scale.

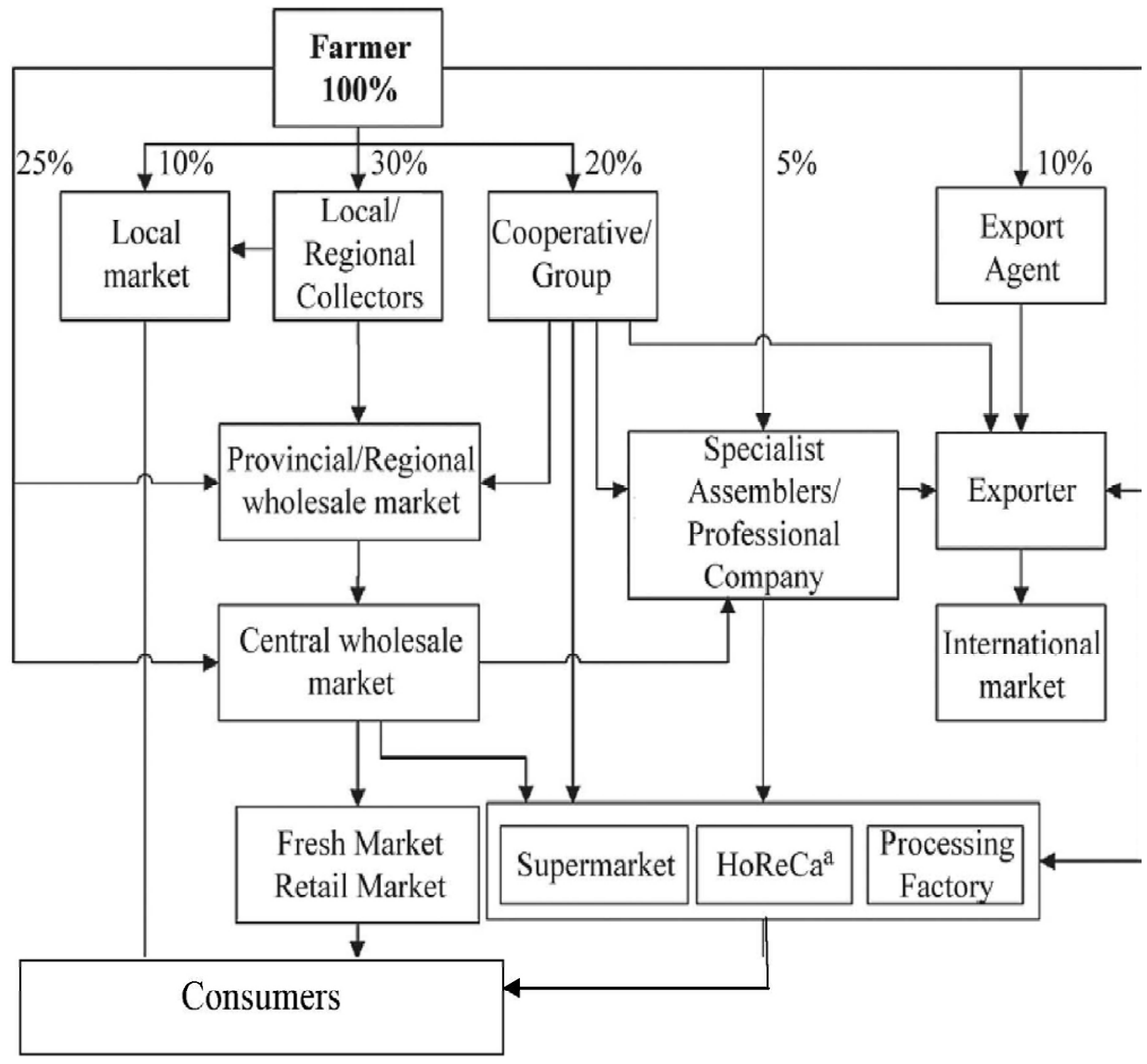

Hotels, Restaurants and Catering

Fig. 6: Supply chain for fruits and vegetables followed in Thailand 


\section{Technological interventions for reducing Post-Harvest losses}

\section{Pre-cooling and storage structures}

Harvesting methods and time of harvest play an important role in storage life of the fruit. Harvesting of fruits, such as mangoes at about 2 inches from their tip on the peduncle using mechanical harvesters (Fig.7) helps in improving the keeping quality of the mangoes. Harvesters for fruits, like citrus fruits, sapota, etc. help in reducing the damage/injury to such fruits, eventually leading to extended storage life for such fruits.

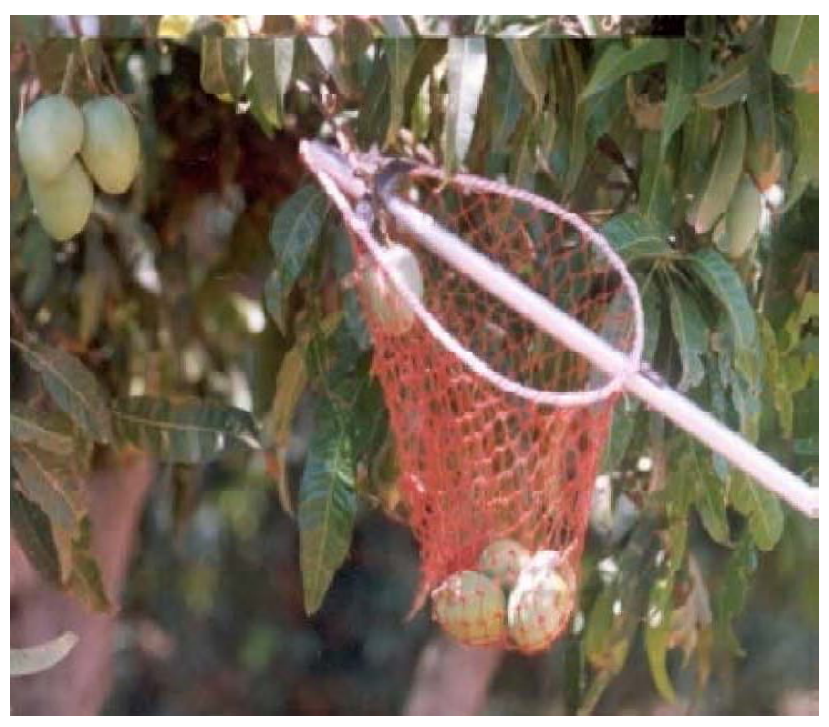

Fig. 7: Simple mango harvesters developed at ICAR-IIHR, Bengaluru

Pre-cooling of fruits reduces the field heat, thereby reducing the respiration rate and physiological activity in the fruits, thereby minimizing the spoilage. In addition, pre-cooling also helps in reducing the physiological loss in weight (PLW), thus helping in preservation of the value of the fruits. Pre-cooling also helps in delaying ripening and retarding senescence. Pre-cooling is extremely important for tropical fruits, as the temperatures during harvest are relatively high and therefore, the fruits need to be immediately pre-cooled for having an optimal shelf life. Different methods of pre-cooling include

- Hydro cooling which requires the use of cold water or cold water spray. Hydro cooling is generally achieved through flooding, immersion or spraying of cold water.
- Air-coolingwhich involves the use of refrigerated air as pre-cooling medium and this method is suitable for tropical fruits. Pre-cooling with air can be accomplished in a conventional cold storage room, a special pre-cooling, a funnel cooler, or a forced air cooler.

- Vacuum cooling that works on the principle of cooling by reducing atmospheric pressure in artificial hermetically sealed chambers. The major advantages of vacuum cooling are the speed and uniformity of cooling of the produce. Vacuum cooling is generally found to be useful and suitable for vegetables.

In order to save the fresh produce, it is suggested to have the pre-cooling facility at the farm gate or in the vicinity of the farmer's field. Pre-cooling at $10^{\circ} \mathrm{C}$, packing in LDPE bags of 200-gaugethickness without vents followedby storage at $10^{\circ} \mathrm{C}$ resulted in optimum quality and minimal spoilage in guava (Dhara et al., 2017). Ravikumar et al. (2018) reported that banana cv. Grand Naine fruits pre-cooled with hydro cooling (spray at $13^{\circ} \mathrm{C}$ and stored in cold store at $13{ }^{\circ} \mathrm{C}$ ) showed good shelf life. Kanade et al. (2017) reported that among all the treatments, pre-cooling at $12{ }^{\circ} \mathrm{C}$ followed by storage at $15{ }^{\circ} \mathrm{C}$ helped in extending the shelf life of fruits of mango cv. Alphonso to 28 days.

\section{On- farm primary processing}

Deterioration in fruits occurs largely due to factors, such as temperature, oxygen, light, moisture, and microbial growth. Deterioration process accelerates once these factors act together, resulting in fast spoilage of fruits. Tropical fruits like mango, guava and papaya generally come to harvest during hot and humid periods, such fruits being high in moisture with very less protection are vulnerable to deterioration because of physiological, biochemical and microbiological spoilage. Oxygen essentially provides conditions that enhance growth of aerobic microbes. Presence of oxygen enhances the growth of microorganisms, such as molds and yeasts, and contributes directly to deterioration in fats, vitamins, flavors, and colors within fruits through the action of enzymes.

Therefore, it is extremely important to have a disinfection facility at the farm level to have a good/ optimal shelf life for fresh fruits. Ozone is the 
strongest food grade antimicrobial agent. While destroying bacteria and viruses, the remaining ozone reverts to oxygen, for a pure, fresh taste without any chemical residue. Ozone is environmental friendly, quick, simple and effective against bacteria, pesticides, poisons and prolongs the storage life naturally. Ozone is reported to have 1.5 times the oxidizing potential of chlorine and 3,000 times the potential of hypochlorous acid (HOCl). Contact times for antimicrobial action with ozone are typically 4-5 times less than that of chlorine. Ozone rapidly attacks bacterial cell walls and is more effective against the thick-walled spores of plant pathogens and animal parasites than chlorine, at practical and safe concentrations (Suslow, 1998). Application of electrolyzed water has been primarily focused on fruits and vegetables; its potential for surface decontamination of food products still requires further study and optimization. Especially, application parameters, such as $\mathrm{pH}$, oxidation reduction potential (ORP), temperature, treatment time, and active chlorine concentration, require optimization for washing fresh fruits to increase the microbiocidal effect of electrolyzed water washing as a promising alternative technique (Turantas et al., 2018). In some of the countries like USA, UK, washing and/or disinfection using electrolyzed water or ozone is done at the farmer's field. This helps in not only controlling the spoilage microorganisms as well as the food borne pathogens but also helps in reduced biochemical activity, resulting in a better storability of the produce.

\section{Packaging and transportation}

Cold storage of mango at $12-13^{\circ} \mathrm{C}$ is appropriate only for 2-3 weeks, beyond which the fruits tend to deteriorate rapidly. Cold storage limits the use of sea freight, which is usually more economical and ecofriendly than airfreight. Controlled atmosphere (CA) storage involves regulating the concentration of oxygen $\left(\mathrm{O}_{2}\right)$ and carbon dioxide $\left(\mathrm{CO}_{2}\right)$ using nitrogen, a right mix of storage temperature and relative humidity $(\mathrm{RH})$ in the storage environment. Controlled atmosphere in combination with an optimum storage temperature prolongs the storage life and helps in maintaining the fruit quality including aroma volatiles in mango fruit depending upon the cultivar (Singh and Zaharah, 2015). Elhefny et al. (2012) reported that the optimal CA for long term storage of "Keitt" mango at $13{ }^{\circ} \mathrm{C}$ with $3 \% \mathrm{O}_{2}+6 \% \mathrm{CO}_{2}+91 \% \mathrm{~N}_{2}$ could extend the storage life up to 10 weeks. Shelf life of 3 months is ideal for export of mangoes through the sea route. Rao et al. (2018) have presented a consolidated information on different storage and packaging techniques to extend the shelf life of tropical fruits, which includes shrink wrapping, modified atmosphere packaging (MAP) and controlled atmosphere (CA) storage.

Transportation of tropical fruits from the farmer's field to the retail stores or CC of the supply chain companies is one of the major operations having a direct impact on the $\mathrm{PH}$ losses and shelf life of the produce. Generally, the tropical fruits require a temperature ranging from $12-15{ }^{\circ} \mathrm{C}$ and $\mathrm{RH}$ ranging from $85-95 \%$ for optimal storage. If the similar conditions could be provided during transportation, the $\mathrm{PH}$ losses in such fruits can be brought down significantly. Studies conducted by ICAR-IIHR, Bengaluru on solar operated evaporatively cooled vans for retail sale of fruits and vegetables have shown an extended shelf life of fruits by 36-48 hours depending on the ambient conditions (Fig 8a). Evaporative cooling through misting helped in increasing the $\mathrm{RH}$ to the tune of $80-85 \%$, which subsequently helped in reducing the physiological loss in weight (PLW) and retained freshness in fruits and vegetables. Incorporation of phase change material (PCM) [Fig. $8 \mathrm{~b}$, such as gel packs also help in reducing the temperature, therebyhelping in extending the storability of tropical fruits. Integrating the incorporation of PCM along with the misting system and running this system through solar power is the need of an hour. Such kind of storage vans which do not use the fuel of the vehicle for evaporative cooling/cooling mechanism are suitable for short distance transportation as well and will help in reducing the carbon footprint. Integrating the use of solar power and PCM not only will reduce the environmental pollution but also help in saving energy.

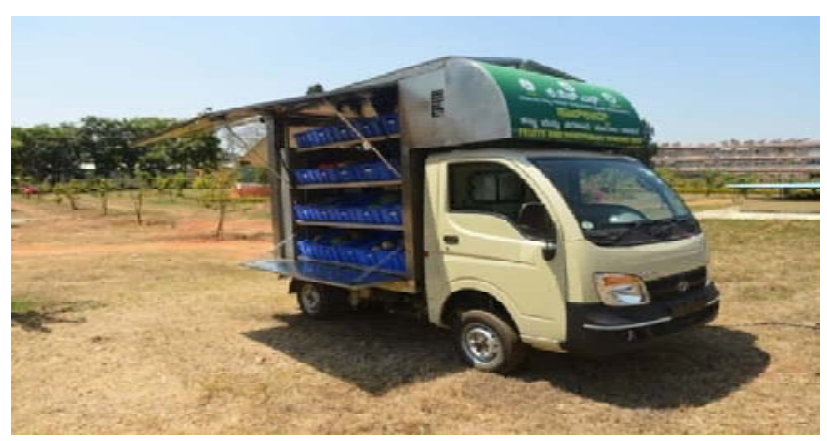

Fig. 8: a. Fruit and vegetable vending van using the solar power and evaporative cooling mechanism through misting for maintaining high $\mathrm{RH}$ inside the structure 

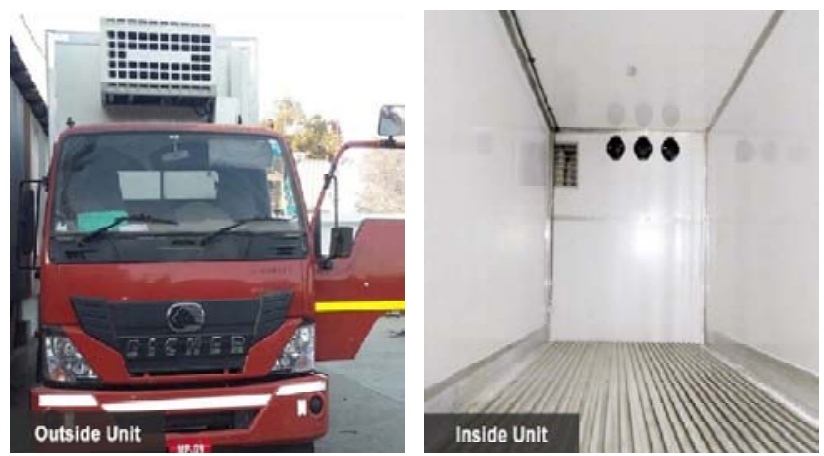

Fig. 8: b. Vending van using the Phase Change Material (PCM) for maintaining low temperature during transportation

Establishment of on-farm storage structures based on evaporative cooling/ refrigeration and hybrid systems help in improving the shelf life of the fresh horticultural produce. Increase in humidity to about $90 \%$ with a decrease in temperature by $10-12{ }^{\circ} \mathrm{C}$, compared to ambient temperatures help in improving the shelf life of the tropical fruits. On-farm establishment of evaporative cooled (EC) storage structures help in reducing the $\mathrm{PH}$ losses in fruits and vegetables (Chopra et al., 2004). On-farm storage structures like the ICAR-CIPHET designed evaporatively cooled structure (Fig. 9a) or the refrigerated structures (Fig. 9b)can serve as ideal structures for pre-cooling as well as storage to improve the shelf life of fruits as well as avoid distress sale of the fresh fruits.
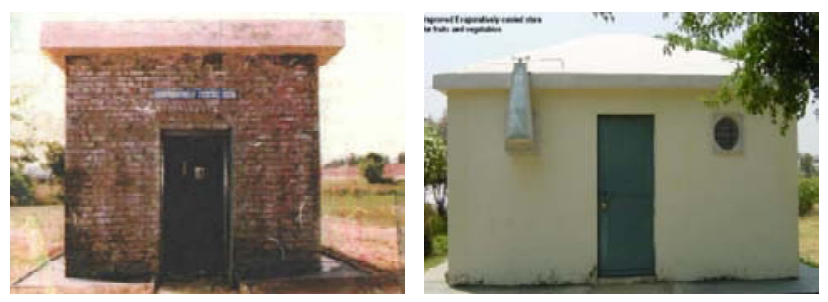

(a)

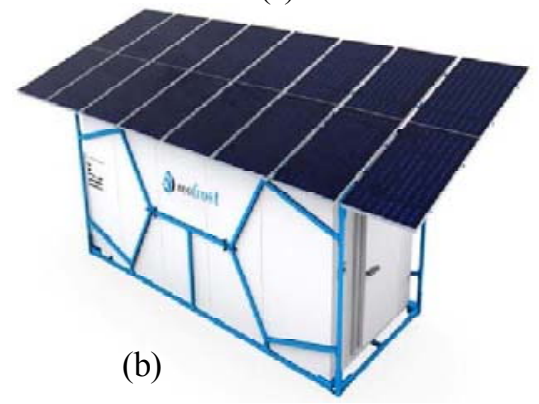

Fig. 9: (a) Evaporatively cooled structures and (b) Solar power refrigerated structure for on-farm pre-cooling and storage of fruits and vegetables
In addition to on-farm storage and/or pre-cooling, onfarm primary and secondary processing of fruits will help in adding significant value to the fruits and improve their shelf life. Primary and secondary processing facility for sorting, washing, grading, waxing (wherever required) and packaging at the farm gate will improve the marketability of the fruits, in addition to improving their shelf life. Creation of secondary processing activities at the farm gate level, for fruits such as mango, guava, papaya pulp processing facility with the product having a shelf life of six months or more will help the farmer/FPO to add value to the fruit and enable them to sell the product at the appropriate time, whenever demand of such products is on the rise.

\section{Tracking and traceability of the produce}

Tracking of the fresh fruits through the supply chain helps in monitoring the movement of the produce throughout the chain. Traceability of the produce gives details about the farmer who produced the fruits, planting date, spray schedule, quality of water used for irrigation, test reports and harvesting date, so that the information could be put to use for improving the cultivation practices at the time of recall. With the traceability system in place, one can identify the root cause for the pathogen infestation or epidemic outbreak so that appropriate preventive action could be taken to ensure that such epidemics do not recur. Information about traceability can be incorporated in the farm of bar codes and readable radio frequency identification (RFID) tags and can be made available to a person sitting at a distant place through a mobile app. During the supply chain, installation of the RFID tags on the crates and integrating them with the sensors for temperature, $\mathrm{RH}$, weight, ethylene production and biosensors in the transport vehicles will help in reducing the wastages in the supply chain (Oberoi, 2008). Such information once made available to the farmer/ producer on a mobile or any other device will help him in deciding if the produce needs to be diverted to a processing unit during transportation to the destination because of the deterioration in the quality of the produce or could be taken to the destination (Fig. 10). This is an important innovation, which will help in significantly reducing the transit losses in perishable commodities. 


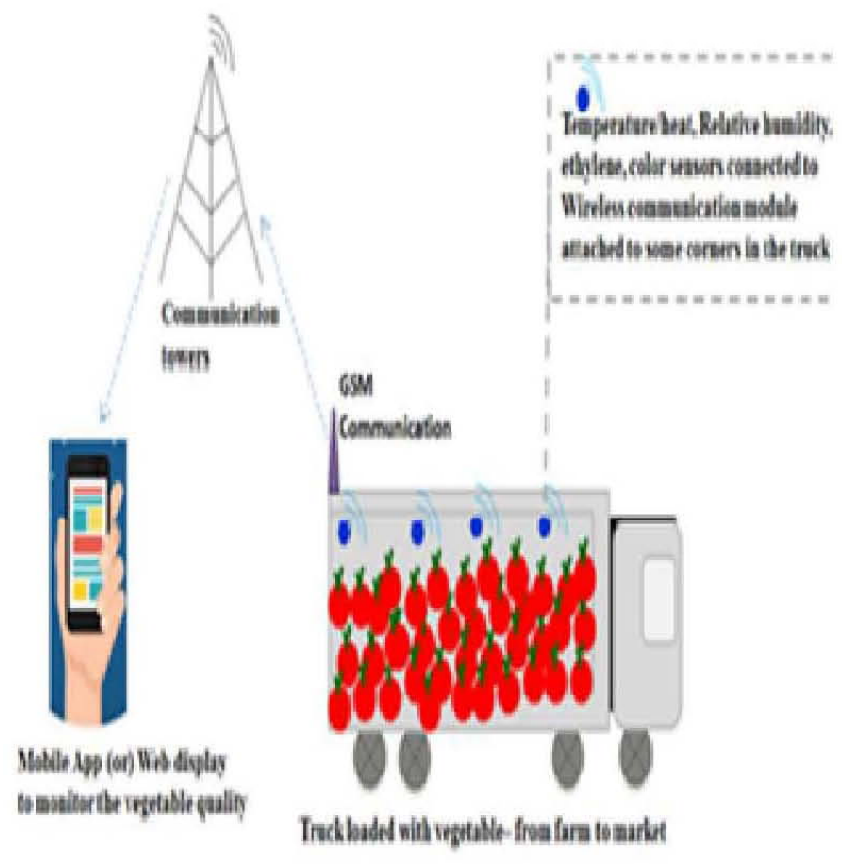

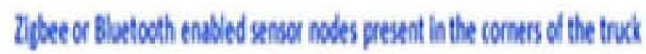

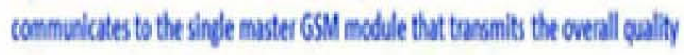

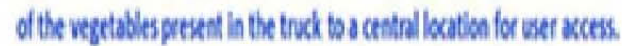

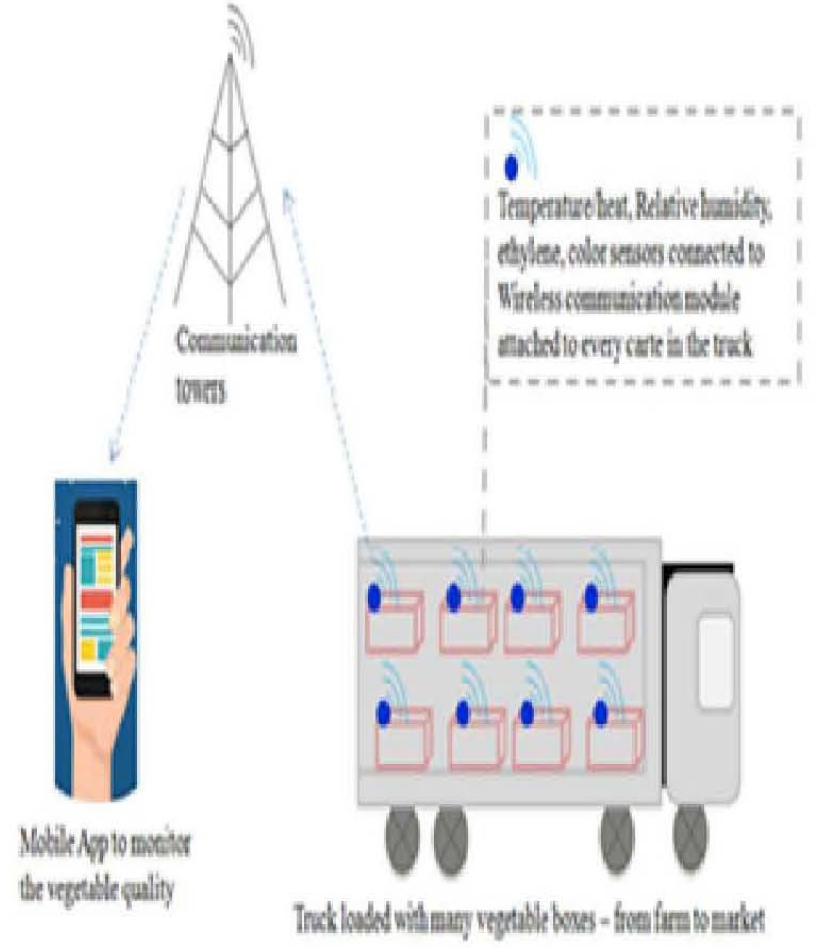

Fig. 10: Traceability studies integrating the RFID tags with different sensors for the produce transported directly or in crates in the trucks

\section{Conclusion}

Value chain integrates different actors in the chain of operations right from the farmers to consumers, involving technological innovations so that the value addition takes place at each stage. In case of fruits, value chain deals with value addition in monetary terms at each stage of the value chain and quality maintenance throughout the value chain. It is extremely important to have a shorter supply chain to ensure the delivery of quality output to the consumer. Farmers/ FPOs need to be educated about suitable varieties, GAP, use of micronutrients and biopesticides, nutrient use management, mechanization in field operations and better irrigation techniques, thus helping in production of quality and uniform output. Efficient crop planning and use of market intelligence and integrating them with GAP will help in adding value to the farm produce. Establishment of on-farm primary processing and storage facility including the facility for pre-cooling and cold storage is extremely important to preserve the quality and nutritional value of the fruits. Appropriate packaging, such as packaging of fruits in punnets using laser microperforated films or other appropriate films creating MAP and CA storage are important techniques for value addition to the tropical fruits, such as mango and banana. Transportation of tropical fruits using refrigerated containers or wherever possible, evaporatively cooled containersusing renewable sources of energy, such as solar energy will help in extending the shelf life of fruits.Tracking and traceability of the fresh produce using the RFID tag, sensors, bar codes help in effective monitoring of the produce through the supply chain. Formation of more and more farmer producing organizations (FPOs) will help in improving the bargaining power of the farmers and in creation of on-farm storage and processing facilities. Creating on-farm processing will help in improving the shelf life of tropical fruits and add value to them through processing facilities. 


\section{References}

Chang, K., Brattlof, H. and Ghukasyan, S. 2014. Smallholder participation in the tropical superfruits value chain: ensuring equitable share of the success to enhance their livelihood. FAO, www.fao.org

Chopra, S., Aleksha Kudos, S,K., Oberoi, H.S., Baboo, B., Mahmood Ahmad, K.U. and Kaur, J. 2004. Performance evaluation of evaporative cooled room for storage of Kinnowmandarin. Journal of Food Science and Technology, 41: 573-577.

Dhara, P., Patel, N.L., Ahmad, T., Patel, A. and Kumar, V. 2017. Effect of Pre-cooling, packaging material on chemical and sensory quality of Guava fruits [Psidium guajava (Linn.)] cv Allahabad Safeda. Environment and Ecology, 35 (1): 64-69.

Elhefny, A.A., Gyulakhmedov, S.G., El-Hefnawi, S.M., Gad, M.M. and Kuliyev, A.A. 2012. Effect of controlled atmosphere storage (CAS) on phosphofructokinase activity in mango (Mangiferaindica L.) cv. Keitt. JKAU: Met., Env. \& Arid Land Agric. Sci.,23: 15-28

Jha, S.N., Vishwakarma, R.K., Ahmad, T., Rai, A. and Dixit, A.K. 2016. Report on quantitative harvest and post-harvest of major crops/commodities in India， DOI: 10.13140/RG.2.1.3024.3924

Kanade, N.M., Pawar, C.D., Ghule, V.S., Gajbhiye, R.C., Salvi, B.R. 2017. Effect of different precooling and storage temperatures on shelf life of mango cv. Alphonso. International Journal of Current Microbiology and Applied Science, 6 (11): $845-855$

Kaplinsky, R. and Morris, M. 2000. A Handbook for Value Chain Research. IDRC.

http://www.ids.ac.uk/ids/global/pdfs/VchNov01.pdf

Oberoi, H. S. 2018. Status and advances in post harvest technology in horticulture. Presentation made during National Seminar on Post Harvest Handling, Ambient Controlled Storage \& Supply Chain Management, held at ICAR-CIRCOT, Mumbai on February 2.
Rao, D.V.S., Narayana, C.K., Bhuvaneswari, S., Senthilkumaran, G., Rathinakumari, C. and Oberoi, H.S. 2018. Post harvest management of tropical and sub-tropical fruits, Technical Bulletin No.70, ICAR-IIHR, Bengaluru

Ravikumar, M., Desai, C.S., Raghavendra, H.R. and Naik, P. 2018. Effect of pre-cooling in extending the shelf life of banana cv. Grand Naine stored under different storage conditions. International Journal of Chemical Studies, 6(3): 872-878.

Salami, P., Ahmadi, H., Keyhanim A. andSarsaifee, M. 2010. Strawberry post-harvest energy losses in Iran. Researcher, 4: 67-73.

Sihariya, G., Hatmode, V.B. and Nagadevara, V. 2013. Supply chain management of fruits and vegetables in India, Tenth AIMS International Conference on Management, Bengaluru, India, January 3-6.

Singh, Z. and Zaharah, S.S. 2015.Controlled atmosphere storage of mango fruit: Challenges and thrusts and its implications in International Mango Trade. In Proc. of the global conference on augmenting production and utilization of Mango: Biotic and abiotic stresses Eds.: H. Ravishankar et al. Acta Hort. 1066:179-191

Srimanee,Y.and Routray, J.K. 2012. The fruit and vegetable marketing chains in Thailand: Policy impacts and implications. International Journal of Retail \& Distribution Management, 40 (9), 656-675.

Sukvinder-Jassi, A. P. 2011. United Kingdom Food Supply Chain. Heslington: Improve Limited.

Suslow, T. 1998.Basics of ozone applications for postharvest treatment of fruits and vegetables. Perishables handling. quarterly Issue No. 94, University of California, Davis, USA

Turantaş F., Ersus-Bilek, S., Sömek, O. and Kuşçu, A. 2018. Decontamination effect of electrolyzed water washing on fruits and vegetables. Journal of Microbiology, Biotechnology and Food Science, 7(4): 337-342. 